\title{
The upstream sequence of the phycocyanin $\beta$ subunit gene from Arthrospira platensis regulates expression of $g$ fp gene in response to light intensity
}

\author{
Yongzhong Lu \\ College of Marine Life Sciences \\ Ocean University of China \\ Qingdao, 266003, P. R.China \\ Tel: 08605327084000 \\ E-mail: luyz@yahoo.com \\ Xuecheng Zhang* \\ College of Marine Life Sciences \\ Ocean University of China \\ Qingdao, 266003, P. R.China \\ Tel: 08605322032789 \\ E-mail: xczhang@ouc.edu.cn
}

Financial support: National Natural Science Foundation of China (No. 30471317).

Keywords: $с р с B$ gene, deletion analysis, light intensity, Synechococcus, transformation.

Abbreviations: PCR: polymerase chain reaction;

GFP: green fluorescent protein;

MCS: multiple cloning site.

In cyanobacteria, few details are known of the mechanisms through which the expression of the lightharvesting pigment c-phycocyanin is regulated. In the present study, a 419 bp upstream sequence of the phycocyanin $\beta$ subunit $(c p c B)$ gene from Arthrospira platensis FACHB341 was fused with green fluorescent protein $(g f p)$ gene, and a heterologous reporting system was built up to investigate the influence of light intensity on the expression of $g f p$ gene, and the regulation function of different region of the upstream sequence of срсB gene. Results showed that the upstream sequence of $\boldsymbol{c p c B}$ gene could drive the expression of $\mathrm{gfp}$ gene in Synechococcus sp. strain PCC7942, and the expression was influenced by light intensity, the lower the light intensity, the higher the GFP level. Deletion analysis revealed that a light-responsive element was located in the region -276 to-218, a promoter sequence was in the region -85 to -1 , and two positive cis elements were in the -419 to -276 and the -218 to -130 regions, respectively.

Arthrospira (Spirulina) is an economically important filamentous cyanobacterium. The high content of proteins, essential amino acids, vitamins, minerals and fatty acids makes it an ideal healthy food (Ciferri, 1983). It is worthwhile to mention that this alga is rich in cphycocyanin, and the content can be up to 10 15\% (Zhang, 1998), which has drawn attention, not only for the contribution to photosynthesis and photosynthetic evolution research (Wang et al. 1996), but also for the great potentials in pharmaceutical usage (Bhat and Madyastha, 2000; Padyana et al. 2001; Wang et al. 2001; Reddy et al. 2003; Subhashini et al. 2004). C-phycocyanin consists of $\alpha$ - and $\beta$-subunits encoded by $c p c \mathrm{~A}$ and $c p c \mathrm{~B}$ gene, respectively. It has been found that the organization of c-phycocyanin operon is highly conserved in cyanobacteria; the $с р c B$ and срсA genes are always closely linked and co transcribed with $c p c B$ gene located upstream (Kalla et al. 1988).

Though a lot of attention has been paid to the pharmacological function and protein features of the cphycocyanin from Arthrospira, only a coding region sequence of the c-phycocyanin gene from Arthrospira maxima has been reported ( $\mathrm{Yu}$ et al. 2002). To our knowledge, there is no report on the upstream sequence of срсB gene of Arthrospira. Recently, a 2086 bp fragment of Arthrospira platensis FACHB341 has been cloned in our laboratory, including the complete $c p c B$ gene and the 419 bp upstream sequence. Investigation of the upstream

\footnotetext{
* Corresponding author
} 
Lu, Y. and Zhang, $X$.

Table 1. Primers used in this study.

\begin{tabular}{|c|c|c|}
\hline Primers & Sequences & Applications \\
\hline $\mathrm{P} 1$ & 5-CCCAAGCTTGAATGCTTGTATTGACC & \multirow[t]{2}{*}{ To clone the upstream sequence } \\
\hline P2 & 5-GCGTCGACGGATTTATCTCCTCTTG & \\
\hline P3 & 5-ATGGTGAGCAAGGGCGAG & \multirow[t]{2}{*}{ To delete the additional sequence } \\
\hline P4 & 5-GGATTTATCTCCTACTTG & \\
\hline P5 & 5-CCTGCGTTATCCCCTGATTCTGTGG & \multirow[t]{2}{*}{ To select the deletion mutants } \\
\hline P6 & 5-GAACAGCTCCTCGCCСTTGCTCACC & \\
\hline P7 & 5-CATGCAGACTTACAACAACCC & \multirow[t]{2}{*}{ To clone the isiAB gene fragment } \\
\hline P8 & 5-AGCCAACTGTTTGACTACC & \\
\hline PdL & 5-TCAATACAAGCATTCAAG & \multirow{6}{*}{$\begin{array}{l}\text { Paired with the below primers to produce a } \\
\text { series of } 5^{\prime} \text { end deletion mutations of the } \\
\text { upstream sequence of } c p c B \text { gene }\end{array}$} \\
\hline PdR1 & 5-AGAAGGAAGGCGAATGTTG & \\
\hline PdR2 & 5-АТТСТТСТСАТАААСССТG & \\
\hline PdR3 & 5-AGCCTTTGTCGATGGTTCG & \\
\hline PdR4 & 5-ACCGATGGATTGATTGTCG & \\
\hline PdR5 & 5-СССААСТСААСТСТААGC & \\
\hline
\end{tabular}

Note: HindIII site (AAGCTT) and Sall site (GTCGAC) are blackened.

sequence can help to understand the regulation mechanism of a gene, for in most cases, promoters and cis elements are located in the upstream sequence, and play important roles in the gene expression (Werner et al. 2003).

In order to investigate the structure and function of the upstream sequence of $c p c B$ gene from Arthrospira platensis, a heterologous reporting system in Synechococcus sp. strain PCC7942 was constructed, with GFP as the reporter, and a series of functional analyses through deletion mutation were conducted.

\section{MATERIALS AND METHODS}

\section{Materials}

Arthrospira platensis FACHB341 grew in Zarrouk medium, Synechococcus sp. strain PCC7942 grew in medium BG11, and they were both maintained in our laboratory. The $g f p$ reporter gene vector pEGFP-1 was purchased from the Clontech Company. The restriction enzymes, pMD18-T, site-directed mutagenesis kit and other reagents were purchased from TaKaRa Company. Primers used in the study were synthesized by Bioasia Company (Table 1).

\section{Construction of GFP expression vector}

Based on the sequence of the 2086 bp fragment of Arthrospira platensis FACHB341 previously cloned, two primers were synthesized for subcloning the 419 bp upstream sequence of $c p c B$ gene. To ensure correct orientation, a HindIII site was added to the 5' end of the forward primer (P1), and a SalI site to the 5' end of the reverse primer (P2). After PCR amplification, the products were digested with HindIII and SalI, and then linked to plasmid pEGFP-1. The 40 bp additional sequence between gfp gene and the upstream sequence of $c p c B$ gene was deleted through site-directed mutagenesis (P3 and P4). The correct construct was named as pCEGFP.

\section{Site-directed mutagenesis}

TaKaRa MutanBest Kit was applied to produce mutation. Briefly, based on the sequence of the plasmid template, two mutation-creating primers were designed, with their 5'ends adjacent and 3'ends in opposite directions. PCR was carried out with high fidelity Pyrobest DNA Polymerase, the recovered products were blunted, 5'-phosphorylated, selfligated and transformed to E. coli for selecting the mutants, and the mutants were verified by DNA sequencing.

A series of 5' end deletion mutants of the upstream sequence of $с p с B$ gene were obtained through this method. With the plasmid pCEGFP as the template, the mutationcreating primers were designed (Table 1 ), the positions of the reverse primer (PdL) and the forword primers (PdR1, PdR2, PdR3, PdR4, PdR5) on the upstream sequence of $c p c B$ gene were marked in Figure 1. When PCR conducted, the reverse primer was paired with the forward primer respectively, and the deletion constructs were selected by PCR with primers P5 and P6, which were on each side of the upstream sequence of $c p c B$ gene.

\section{Construction of the homologous recombination vectors}


The isiAB locus of Synechococcus sp. PCC7942 was selected to integrate the GFP expression cassettes. At first, a $1.7 \mathrm{~kb}$ fragment of $i s i A B$ was amplified by PCR with primers P7 and P8, and ligated with cloning vector pMD18$\mathrm{T}$ to get the plasmid pTab. In order to make it suitable for construction of the integration vector, some changes had to make on pTab, mainly including deletion of the EcoO109I site on the vector through digesting, blunting and religation, deletion of the EcoRI site in MCS by site-directed mutagenesis, and introduction of an EcoO109I site in the middle of the $i s i A B$ fragment near the inherent EcoRI site by the same method. Then the modified pTab was digested with EcoRI and EcoO109I, the resultant fragment was ligated with the EcoRI-EcoO109I segments of the GFP expression cassettes, which contained different mutation of the upstream sequence of $c p c B$ gene. The transformants were selected on the LB plate containing $50 \mu \mathrm{g} / \mathrm{ml}$ Kanamycin and $50 \mu \mathrm{g} / \mathrm{ml}$ Ampicillin. The constructed integration vectors with about 800 bp isi $A B$ fragment on each side of the GFP expression cassettes were used to transform Synechococcus sp.

\section{Natural transformation of Synechococcus sp}

The algal cells were collected by centrifugation when the $\mathrm{OD}_{730}$ reached to $0.25 \sim 0.35$, and rinsed with $10 \mathrm{mM} \mathrm{NaCl}$, then transferred to $1 \mathrm{ml}$ BG11 and mixed with $1 \sim 2 \mu \mathrm{g}$ integration vectors. After cultivation overnight in the dark, the mixture was transferred to the BG11 plate containing 5 $\mu \mathrm{g} / \mathrm{ml}$ Kanamycin, and cultivated till the algal colonies appeared (Tsinoremas et al. 1994). The recombinants were identified by PCR, and some colonies of the transgenic alga were picked up and magnified in liquid BG11. In this study all the algal strains were cultured at $28^{\circ} \mathrm{C}$.

Detection of the expression of GFP in the recombinant Synechococcus sp

The algal cells expressing GFP were observed under the fluorescent microscope with excitation wavelength $488 \mathrm{~nm}$

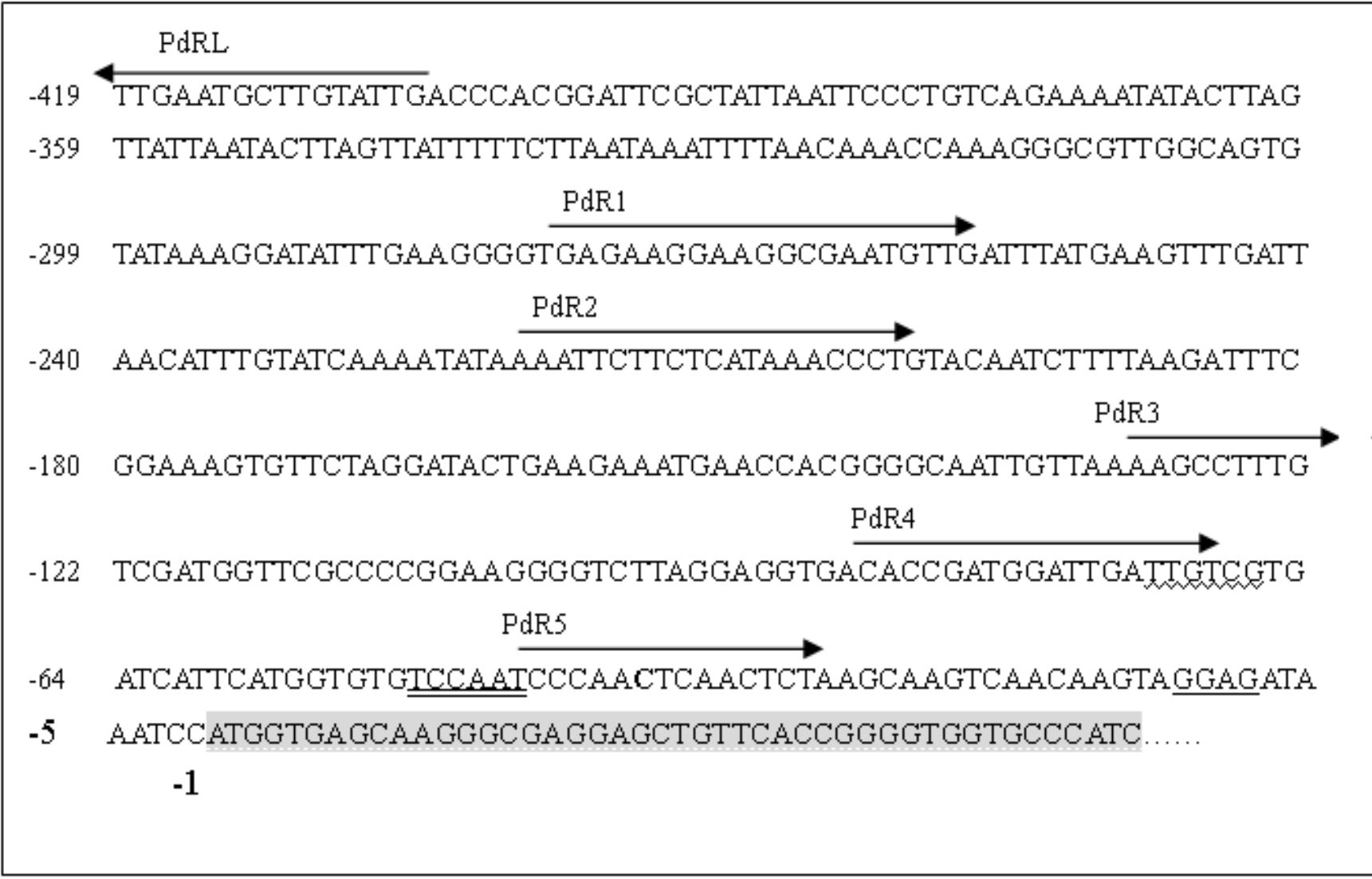

Figure 1. Sequences of the upstream sequence of $c p c B$ gene and the fused gfp gene -419 to -1 : the upstream sequence of $c p c B$ gene;

partial gfp gene sequence;

$\longrightarrow$ mutation primers;

' $C$ ' at the 3 'end of the upstream sequence designated -1 ;

\footnotetext{
- putative SD sequence;

= putative -10 region;

mutative -35 region.
} 

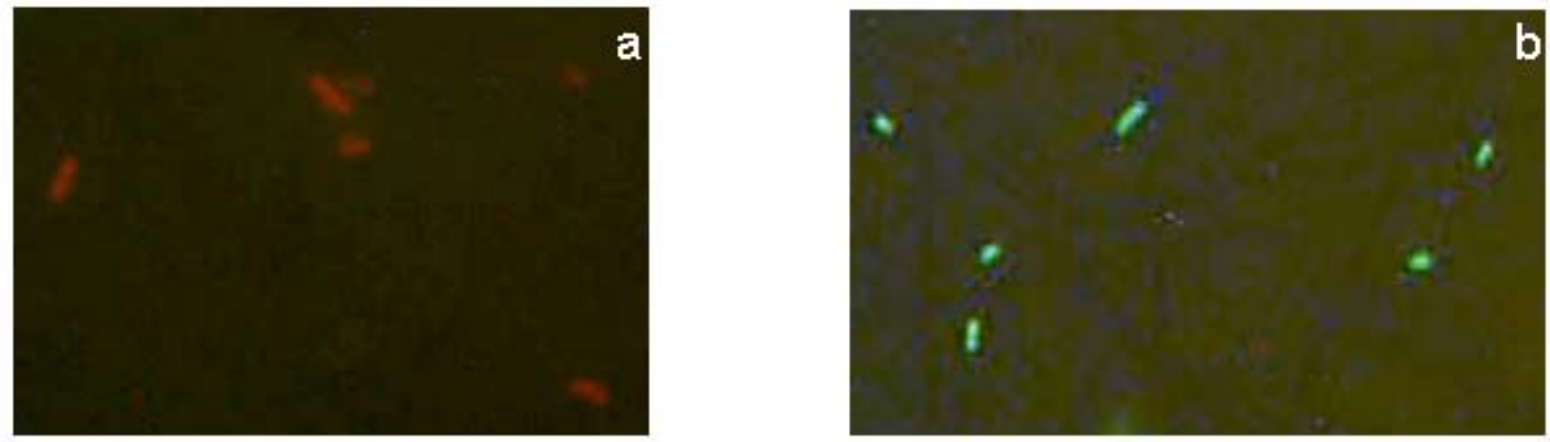

Figure 2. Observation of the recombinant alga under the fluorescent microscope.

(a) The control Synechococcus sp PCC7942.

(b)The recombinant alga So.

and emission wavelength $507 \mathrm{~nm}$, and the GFP level was measured by flow cytometry with cell number of the samples over $10000 \mathrm{ml}$ (Ducrest et al. 2002).

\section{RESULTS}

\section{Subcloning of the upstream sequence of $c p c B$ gene in the pEGFP-1}

It was verified by DNA sequencing that the upstream sequence of $c p c B$ gene was linked with the $g f p$ gene in correct orientation, the 40 bp additional sequence was deleted, and no unexpected mutation occurred on the upstream sequence of $c p c B$ gene and $g f p$ gene (Figure 1).

\section{Expression of GFP driven by the upstream sequence of $c p c B$ gene}

About 15 days after transformation with the integration vector pINT0, which contained the 419 bp upstream sequence of $c p c B$ gene, tiny algal colonies appeared on the BG11 plate. Some colonies were selected and transferred to the liquid BG11 containing $10 \mu \mathrm{g} / \mathrm{ml}$ Kanamycin for amplification. Under fluorescent microscope, all the recombinant algal cells were bright green, while the Synechococcus sp. cells were dark red (Figure 2), indicating that the upstream sequence of $c p c B$ gene could drive the expression of GFP in Synechococcus sp.

The expression of GFP could be measured quantitatively by flow cytometry. As demonstrated in Figure 3 that the control had low level of background fluorescence, while the recombinant alga, named as S0, had obviously high level of GFP, and the GFP amount could be read from the X-axis.

\section{Influence of light intensity on the expression of GFP}

To investigate whether the upstream sequence of $c p c B$ gene was light-responsive, the recombinant alga $\mathrm{S} 0$ was cultured in low light intensity $\left(10.0 \mu \mathrm{mol} \mathrm{m} \mathrm{m}^{-2} \mathrm{~s}^{-1}\right)$ and high light

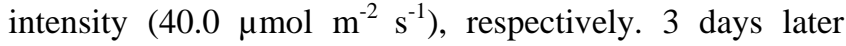
samples were taken to detect the amount of GFP. It was found the GFP level in low light intensity group was higher than in high light intensity group $(\mathrm{p}<0.01)$. To further study the influence of light intensity, the S0 was cultured in several different light intensities (1.0, 10.0, 25.0, 40.0 and $60.0 \mu \mathrm{mol} \mathrm{m}^{-2} \mathrm{~s}^{-1}$ ). It showed again that in the scope of light intensity larger than $10.0 \mu \mathrm{mol} \mathrm{m} \mathrm{m}^{-2} \mathrm{~s}^{-1}$, low light intensity improved the expression of GFP, the lower the light intensity, the higher the GFP level; but light intensity below $10.0 \mu \mathrm{mol} \mathrm{m} \mathrm{m}^{-2}$ might lead to a low GFP expression level (Figure 4).

\section{Deletion analysis on the upstream sequence of cpcB gene}

To define the function of different regions on the $419 \mathrm{bp}$ upstream sequence of $с p c B$ gene, the 5' end deletion vectors of it (pd1, pd2, pd3, pd4 and pd5 )were constructed (Figure 5), and the corresponding recombinant alga was named as S1, S2, S3, S4 and S5. Since there is unique copy of isiAB gene in the Synechococcus genome (Laudenbach and Straus, 1988), the recombinant strain should have one copy of $g f p$ gene, and all the recombinant algal strains are the same except the difference of the 5' end sequences. Therefore, under the same condition, the difference of GFP level of each strain should be determined mainly by the different 5' end sequences.

As demonstrated in Figure 6 that the GFP levels of S0 and $\mathrm{S} 1$ in low light intensity $\left(10.0 \mu \mathrm{mol} \mathrm{m} \mathrm{m}^{-2} \mathrm{~s}^{-1}\right)$ were higher than in high light intensity $\left(40.0 \mu \mathrm{mol} \mathrm{m}^{-2} \mathrm{~s}^{-1}\right)$, however, the GFP levels of S2, S3, S4 in low light intensity were lower than in high light intensity. And under both conditions, the GFP levels of S1 were a little lower than S0, the GFP levels of S3 and S4 were obviously lower than S2, and little GFP was detected from S5. It could be seen clearly when considering Figure 5 and Figure 6 together that, deletion to -276 led to a slight decline of the GFP level, deletion to 218 resulted in a change of the light response, deletion to 130 caused a quick decline of the GFP level, and deletion 


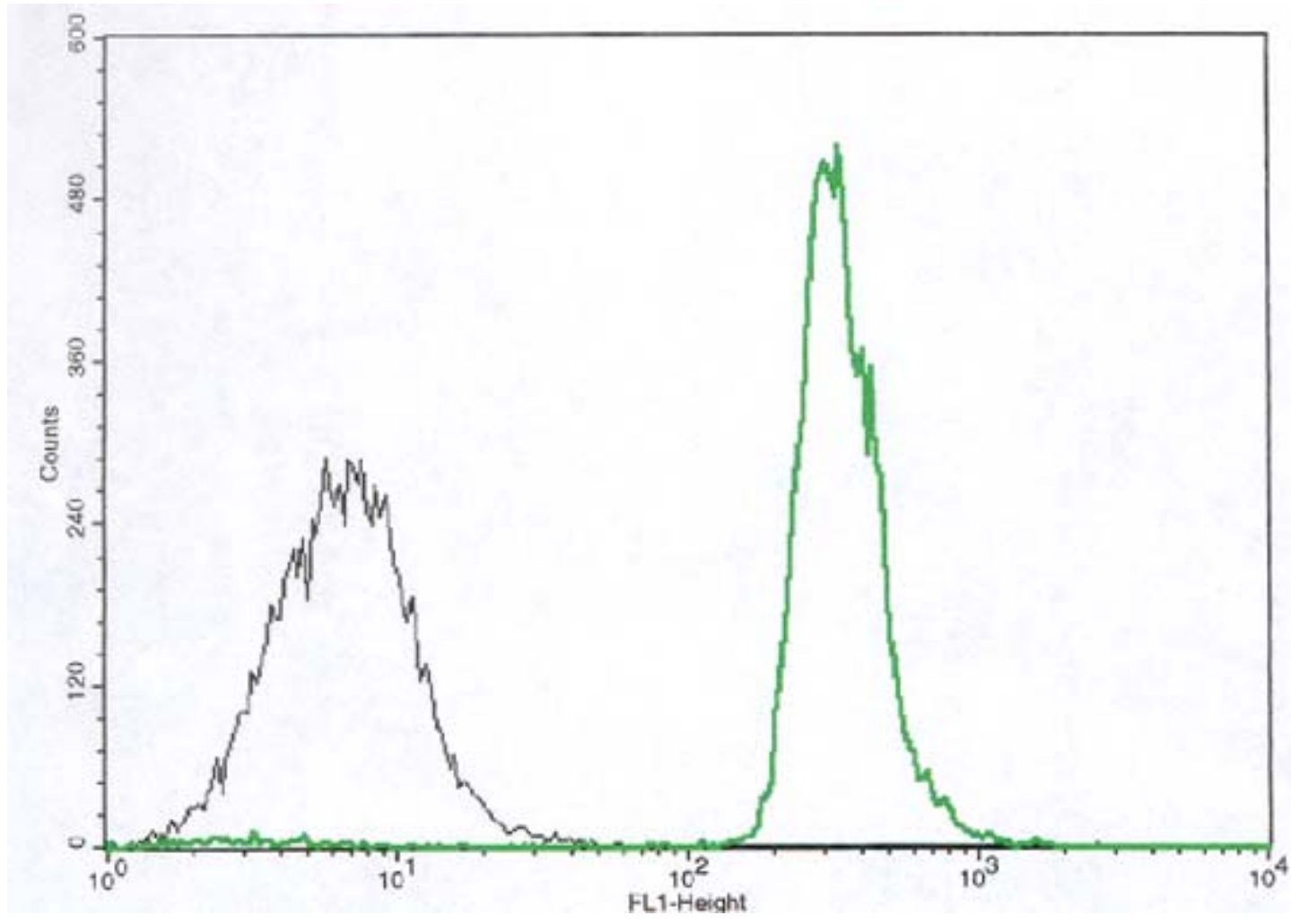

Figure 3. Analysis of GFP expression by flow cytometry. The X-axis stood for the GFP level, and the $Y$-axis stood for the relative cell number. The left peak indicated the control, the right one indicated the recombinant alga, the GFP level could be read according to the location of the peak on the X-axis.

beyond -85 abolished expression of GFP. So conclusions could be drawn from the results that a light-responsive element was possibly located between -276 and -218 , the 85 bp sequence adjacent to the coding region appeared to be the minimum region to keep promoter activity, and there might be some cis elements improving the GFP expression in the regions from -419 to -276 , and from -218 to -130 , respectively.

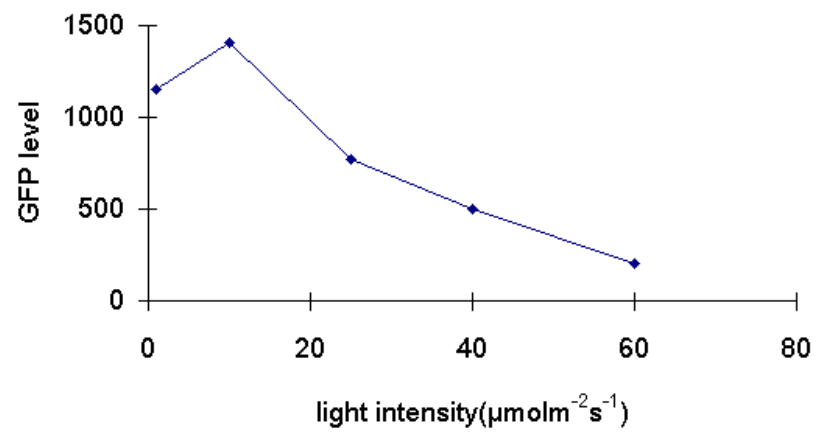

Figure 4. The influence of light intensity on the expression of GFP.

\section{DISCUSSION}

Since no stable genetic transformation system has been established in Arthrospira platensis (Toyomizu et al. 2001), structure and function studies of the upstream sequence of the $с р с B$ gene must rely on a heterologous system. The unicellular cyanobacterium Synechococcus sp. has some advantages for this purpose, firstly, successful transformation methods have been created (Matsuoka et al. 2001); secondly, though taxonomically far from Arthrospira platensis, they are both photoautotrophic organisms capable of oxygen-producing photosynthesis, therefore, some common regulatory system may exist between the two blue-green algae. Proper heterologous systems usually offer important information. It was reported the $p s b A 2$ gene from Synechocystis was also lightdependent and rhythmic in heterologous Synechococcus sp. strain PCC7942 (Agrawal et al. 1999). In this study, the expression of $g f p$ gene in the transgenic alga demonstrated that the cloned upstream sequence of $c p c B$ gene was functional in the heterologous system, and it was possible to get some valuable information on the upstream sequence of $c p c B$ gene with this system.

Whether the $419 \mathrm{bp}$ upstream sequence is long enough to contain all the regulatory elements of $с p c B$ gene is not clear. It is possible that the $с р c B$ gene of Arthrospira platensis has longer upstream sequence, for in many cyanobacteria, a common feature of photosynthesis-related genes is the long leader sequence (Kalla et al. 1988). According to our deletion analysis, deletion to -276 led to a decline of the GFP level, which indicated that there existed 
Lu, Y. and Zhang, $X$.

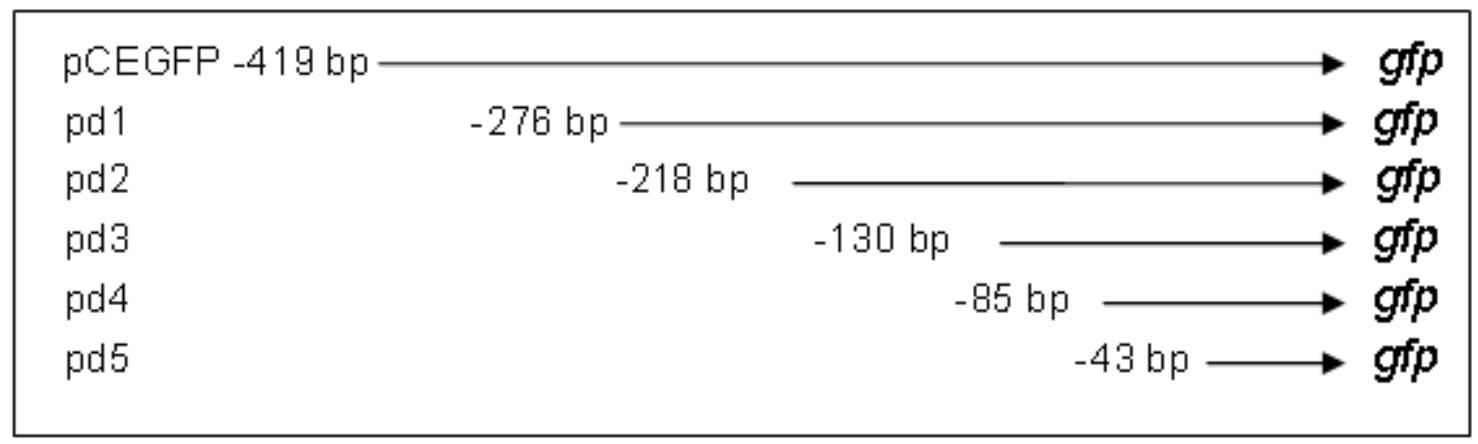

Figure 5. Sketch map of the 5' end deletion constructs.

some regulatory element in the region from -419 to -276 . It is likely that the upstream sequence participating in the regulation of $с р с B$ gene in Arthrospira platensis is longer than 276 bp. A long upstream sequence often indicates complex regulation mechanism; for example, a complex transcriptional pattern was once found for the $c p c B$ gene in Anabaena sp. strain PCC7120 (Belknap and Haselkorn, 1987).

Under high light intensity, the expression of GFP decreased, which was consistent with the report that under low light intensity the amount of phycobiliproteins increased to meet the need of photosynthesis of the alga (Kang et al. 2002). Through deletion analysis a region related to the light response of the $c p c B$ gene was defined. Deletion of this region led to the decrease of expression of GFP under low light intensity, indicating a light responsive cis-element existed in this region. However, it is unclear how this element influences the expression of the gene. In Synechococcus sp. strain PCC7942, the expression of psbAI gene was also down-regulated upon exposure to high light intensity, and the main reasons were accelerated degradation of psbAI mRNA and decreased promoter activity (Nair et al. 2001). It is possible that the lightresponsive element controls the gene expression by influencing the promoter activity and mRNA stability.

A minimal promoter region was also defined through deletion analysis. Promoter analysis to this region characterized the structure of the promoter (Figure 1), including the putative -10 region (TCCAAT), the -35 region (TTGTCG), and the 17 bp spacer region. This is a typical prokaryotic promoter. However, some bases are not conserved in the two elements, which may be related to the function of the promoter in the alga. To our knowledge, no similar sequences have been reported in GenBank, also it is different with the known cyanobacterial promoter sequences. More detailed analysis of the promoter via sitedirected mutagenesis or other methods will be helpful to elucidate its features.

It was also found from deletion analysis that besides the region -419 to -276 , region -218 to -130 played a positive role in the gene expression, for its deletion caused a quick decline of the GFP level. Further identifying the elements and their physiological function will be helpful in understanding the regulation mechanism of $c p c B$ gene.

Though the upstream sequences of $c p c B$ genes in many cyanobacteria were cloned, only the upstream sequence of срсB2A2 gene of Fremyella diplosiphon was once characterized (Casey and Grossman, 1994). More information on the upstream sequences of $c p c B$ genes, including our results here, can contribute to clarify the genetic complexity and diversity of the phycocyanin genes in cyanobacteria. Furthermore, because of the high content of c-phycocyanin in Arthrospira platensis (Belay, 1997; Zhang, 1998), the upstream sequence of $c p c B$ gene is a potential candidate for constructing a high expression vector in cyanobacterial genetic engineering.

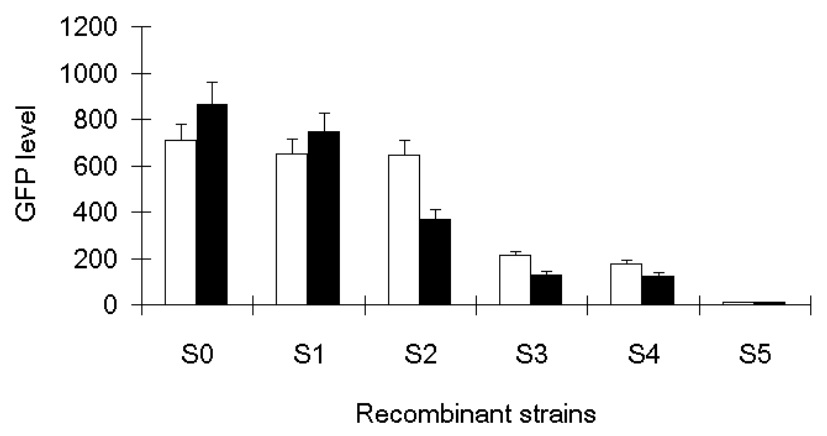

Figure 6. Comparison of GFP levels of different recombinant strains. Each strain contained a different 5 ' end deletion mutation of the upstream sequence of $c p c B$ gene (Figure 5), and their GFP levels in light intensity of $40.0 \mu \mathrm{mol} \mathrm{m} \mathrm{m}^{-2} \mathrm{~s}^{-1}$ and $10.0 \mu \mathrm{mol} \mathrm{m} \mathrm{m}^{-2} \mathrm{~s}^{-}$ ${ }^{1}$ were shown, respectively. $\square \quad$ indicated light intensity of $40.0 \mu \mathrm{mol} \mathrm{m}^{-2} \mathrm{~s}^{-1}$; - indicated light intensity of $10.0 \mu \mathrm{mol} \mathrm{m} \mathrm{s}^{-1}$.

In this study, a preliminary analysis on the upstream sequence of $c p c B$ gene was conducted by deletion mutation, and the influence of light intensity on the expression of $g f p$ gene was also investigated. As reported, other circumstance factors such as light quality, 
temperature, nutrition also influenced the expression of phycobiliproteins. To clarify the relationships between these environmental factors and the upstream sequence, and to learn more about the regulatory elements in this sequence will be our next goal.

\section{REFERENCES}

AGRAWAL, G.K.; ASAYAMA, M. and SHIRAI, M. Light-dependent and rhythemic psbA transcripts in homologous/heterologous cyanobacterial cells. Biochemical and Biophysical Research Communications, February 1999, vol. 255, no. 1, p. 47-53.

BELAY, A. Mass culture of Spirulina outdoors. -The Earthrise Farms experience. In: VONSHAK, A., ed. Spirulina platensis (Arthrospira): Physiology, cell-biology and biotechnology. London, Taylor and Francis. 1997, p.131-158. ISBN 0748406743.

BELKNAP, W.R. and HASELKORN, R. Cloning and light regulation of expression of the phycocyanin operon of the cyanobacterium Anabaena. EMBO Journal, 1987, vol. 6, p. 871-884.

BHAT, V.B. and MADYASTHA, K.M. C-phycocyanin: a potent peroxyl radical scavenger in vivo and in vitro. Biochemical and Biophysical Research Communications, August 2000, vol. 275, no. 1, p. 20-25.

CASEY, E.S. and GROSSMAN, A. In vivo and in vitro characterization of the light-regulated $c p c B 2 A 2$ promoter of Fremyella diplosiphon. Journal of Bacteriology, October 1994, vol. 176, no. 20, p. 6362-6374.

CIFERRI, O. Spirulina, the edible microorganism. Microbiological Reviews, December 1983, vol. 47, no. 4, p. 551-578.

DUCREST, A.L.; AMACKER, M.; LINGNER J. and NABHOLZ, M. Detection of promoter activity by flow cytometric analysis of GFP reporter expression. Nucleic Acids Research [online]. July 2002, vol. 30, no. 14, e65. Available from Internet: http://www.pubmedcentral.nih.gov/articlerender.fcgi?tool= pubmed\&pubmedid=12136113.

KALLA, S.R.; LIND, L.K.; LIDHOLM, J. and GUSTAFSSON, P. Transcriptional organization of the phycocyanin subunit gene clusters of the cyanobacerium Anacystis nidulans UTEX 625. Journal of Bacteriology, July 1988, vol. 170, no. 7, p. 2961-2970.

KANG, R.J.; CAI, Z.L. and SHI, D.J. Studies on the light intensity attenuation in cyanobacterial cultures. Acta Hydrobiologica Sinica, May 2002, vol. 26, no. 3, p. 310-
313.

LAUDENBACH, D.E. and STRAUS, N.A. Characterization of a cyanobacterial iron stress-induced gene similar to psbC. Journal of Bacteriology, November 1988, vol. 170, no. 11, p. 5018-5026.

MATSUOKA, M.; TAKAHAMA, K. and OGAWA, T. Gene replacement in cyanobacteria mediated by a dominant streptomycin-sensitive rps12 gene that allows selection of mutants free from drug resistance markers. Microbiology, August 2001, vol. 147, p. 2077-2087.

NAIR, U.; THOMAS, C. and GOLDEN, S.S. Functional elements of the strong psbAI promoter of Synechococcus elongatus PCC 7942. Journal of Bacteriology, March 2001, vol. 183, no. 5, p. 1740-1747.

PADYANA, A.K.; BHAT, V.B.; MADYASTHA, K.M.; RAJASHANKAR, K.R. and RAMAKUMAR, S. Crystal structure of a light-harvesting protein C-phycocyanin from Spirulina platensis. Biochemical and Biophysical Research Communications, April 2001, vol. 282, no. 4, p. 893-898.

REDDY, M.C.; SUBHASHINI, J.; MAHIPAL, S.V.; BHAT, V.B.; SRINIVAS REDDY, P.; KIRANMAI, G.; MADYASTHA, K.M. and REDDANNA, P. CPhycocyanin, a selective cyclooxygenase-2 inhibitor, induces apoptosis in lipopolysaccharide-stimulated RAW 264.7 macrophages. Biochemical and Biophysical Research Communications, May 2003, vol. 304, no. 2, p. 385-392.

SUBHASHINI, J.; MAHIPAL, S.V.; REDDY, M.C.; MALLIKARJUNA REDDY, M.; RACHAMALLU, A. and REDDANNA, P. Molecular mechanisms in C-Phycocyanin induced apoptosis in human chronic myeloid leukaemia cell line-K562. Biochemical Pharmacology, August 2004, vol. 68 , no. 3, p. 453-462.

TOYOMIZU, M.; SUZUKI, K.; KAWATA, Y.; KOJIMA, $\mathrm{H}$. and AKIBA, Y. Effective transformation of the cyanobacterium Spirulina platensis using electroporation. Journal of Applied Phycology, June 2001, vol. 13, no. 3, p. 209-214.

TSINOREMAS, N.F.; KUTACH, A.K.; STRAYER, C.A. and GOLDEN, S.S. Efficient gene transfer in Synechococcus sp. strains PCC7942 and PCC6301 by interspecies conjugation and chromosomal recombination. Journal of Bacteriology, November 1994, vol. 176, no. 21, p. 6764-6768.

WANG, G.C.; ZHOU, B.C. and ZENG, C.K. Construction of the energy transmission model of Spirulina platensis cphycocyanin and allophycocyanin. Chinese Science Bulletin, April 1996, vol. 40, no. 8, p. 741-743. 
Lu, Y. and Zhang, $X$.

WANG, X.Q.; LI, L.N.; CHANG, W.R.; ZHANG, J.P.; GUI, L.L.; GUO, B.J. and LIANG, D.C. Structure of Cphycocyanin from Spirulina platensis at 2.2 A resolution: a novel monoclinic crystal form for phycobiliproteins in phycobilisomes. Acta Crystallographica Section D Biological Crystallography, June 2001, vol. 57, p. 784-792.

WERNER, T.; FESSELE, S.; MAIER, H. and NELSON, P.J. Computer modelling of promoter organization as a tool to study transcriptional coregulation. The FASEB Journal, July 2003, vol. 17, no. 10, p. 1228-1237.

YU, P.; LI, J.R. and CEN, P.L. Cloning and sequencing of the phycocyanin gene from Spirulina maxima and its evolutionary analysis. Journal of Applied Phycology, August 2002, vol. 14, no. 4, p. 307-310.

ZHANG, X. Large scale cultivation of Spirulina in China: Today and tomorrow. Biosystem Studies, February 1998, vol. 1, no. 1, p. 66-73. 